\title{
ПРАВОВІ ПЦДСТАВИ ВИДОБУТКУ ЕНЕРГЕТИЧНИХ РЕСУРСІВ В МЕЖАХ ВИКЛЮЧНОї ЕКОНОМІЧНОї ЗОНИ УКРАїНИ
}

\author{
УСТИМЕНКО Тетяна Петрівна - к.ю.н., доцент,професор кафедри \\ цивільного права і процесу Національної академії внутрішніх справ \\ https://orcid.org/0000-0003-0049-5608 \\ ШАПОВАЛ Леся Іванівна - к.ю.н., доцент,старший інспектор відділу \\ інспекції з особового складу управління кадрового забезпечення ГУНП У м. Кисві \\ DOI 10.32782/LAW.2020.2.23
}

У статті проаналізовані відповідні норми міжнародного морсъкого права і приписи українсъкого законодавства щодо визначення порядку видобутку енергетичних ресурсів в межах виключної економічної зони Украӥни.

Украӥною у 1999 рочі був прийнятий Закон «Про угоди про розподіл продукиї», який спрямований на створення сприятливих умов для інвестування пошуку, розвідки та видобування корисних копалин, в тому числі вуглеводневої сировини, у межах територї Украӥни, ї континентального шельбу та виключної (морсъкої) економічної зони на засадах, визначених угодами про розподіл продукиій.

Автори зробили висновки про можливість видобутку енергетичних ресурсів (набрти і газу) в межах виключної економічної зони Украӥни як за наявності спеціального дозволу на користування надрами, так $і$ на підставі укладення угоди про розподіл продукиї з обормленням спешіального дозволу на користування надрами.

Ключові слова: прибережні держави, природні ресурси, видобування корисних копалин, виключна (морсъка) економічна зона, Чорне море, Азовське море, вуглеводнева сировина.

Усім відомо, що Україна є однією $з$ найбагатших за своїми природними ресурсами країн Європи, про що свідчать деякі з наведених нижче фактів.

Так, Україна має найбільшу серед держав Азово-Чорноморського басейну довжину морського узбережжя - 2759,2 кілометра i понад 72 тис. кв. кілометрів виключної морської економічної зони.
На українському шельфі Чорного та Азовського морів розвідано значні запаси корисних копалин, зокрема до 1583,5 млрд. куб. метрів природного газу і до 409,8 млн. тонн сирої нафти, що становить понад 30 відсотків загальних запасів вуглеводнів України. При цьому з них видобуто лише 4 відсотки тоді, як із берегових родовищ - до 70 відсотків розвіданих запасів вуглеводнів.

Ураховуючи зазначене, важливість усіх різновидів ресурсів моря зростатиме, а від ефективності реалізації державної морської політики залежать суверенітет і територіальна цілісність України, іiі економічна та енергетична незалежність, сталий розвиток та інтеграція в євроатлантичний політичний, економічний, правовий і безпековий простір ${ }^{1}$ (далі - Морська доктрина).

Згідно із Законом України «Про національну безпеку України» ${ }^{2}$ національна безпека України - захищеність державного суверенітету, територіальної цілісності, демократичного конституційного ладу та інших національних інтересів України від реальних та потенційних загроз. Національні інтереси України - життєво важливі інтереси людини, суспільства і держави, реалізація яких забезпечує державний суверенітет

\footnotetext{
${ }^{1}$ Про затвердження Морської доктрини України на період до 2035 року: Постанова Кабінету Міністрів України від 07.10.2009 p. № 1307. URL: https:// zakon.rada.gov.ua/laws/show/1307-2009-\%D0\%BF.

${ }^{2}$ Про національну безпеку України: Закон України від 21.06.2018 р. URL: https://zakon.rada.gov.ua/laws/ show/2469-19.
} 


\section{Цивільне, підприсмницьке, господарське та трудове право}

України, іiі прогресивний демократичний розвиток, а також безпечні умови життєдіяльності і добробут ії громадян.

Згідно із Морською доктриною до пріоритетних національних інтересів на морі належать задоволення потреб суспільства, економіки і держави у використанні ресурсів моря, посилення позиції України серед провідних морських держав, а також забезпечення безпеки, серед іншого, шляхом:

захисту суверенних прав і юрисдикції України в її виключній (морській) економічній зоні, а також у стратегічно важливих для держави районах моря;

провадження морегосподарської діяльності (використання ресурсів моря для задоволення потреб людини, а також суспільства в цілому та розширеного відтворення природно-ресурсного потенціалу), серед іншого, з вивчення, розвідки, видобування, використання, збереження невідновних та відтворення відновних ресурсів, які не відносяться до водних біоресурсів та мінімізації шкоди навколишньому природному середовищу під час експлуатації ресурсів моря.

Серед основних принципів реалізації державної морської політики у Морській доктрині визначені:

провадження морської діяльності з дотримання законодавства України та ії міжнародних договорів;

захист права власності українського народу на природні ресурси континентального шельфу та виключної (морської) економічної зони України.

Важливим фактором економічного розвитку нашої держави та їі енергонезалежності є створення сприятливих умов для видобування енергетичних природних ресурсів на шельфі Чорного та Азовського морів, розвиток трубопровідної та портової інфраструктури для їх транспортування і постачання. Для цього необхідно суттєво підвищити інвестиційну привабливість українського шельфу, удосконалити економічну і фіскальну політику щодо видобування нафти та природного газу, а також схвалити стратегію освоєння вуглеводневих ресурсів в українському секторі Чорного і Азовського морів.
Стаття 55 КонвенціїОрганізаціїОб'єднаних Націй з морського права ${ }^{3}$ ЮНКлОС визначає, що виключна економічна зона являє собою район, що знаходиться за межами територіального моря і прилеглий до нього, який підпадає під встановлений особливий правовий режим, згідно з яким права і юрисдикція прибережної держави і права та свободи інших держав регулюються відповідними положеннями цієї Конвенції.

Ширина виключної економічної зони не повинна перевищувати 200 морських миль, відлічених від вихідних ліній, від яких відмірюється ширина територіального моря (стаття 57 ЮНКлОС).

На підставі ЮНКАОС Україна прийняла спеціальне законодавство про виключну (морську) економічну зону.

Так, відповідно до статті 2 Закону України «Про виключну морську (економічну) зону України» ${ }^{4}$ морські райони, зовні прилеглі до територіального моря України, включаючи райони навколо островів, що їй належать, становлять виключну (морську) економічну зону України. Ширина виключної (морської) економічної зони становить до 200 морсъких миль, відлічених від тих самих вихідних ліній, що і територіальне море України.

Відповідно до положень статті 4 Закону України «Про виключну морську економічну зону» Україна у своїй виключній (морській) економічній зоні має:

суверенні права щодо розвідки, розробки і збереження природних ресурсів як живих, так і неживих у водах, що покривають морське дно, на морському дні та в його надрах, а також 3 метою управління цими ресурсами і щодо здійснення інших видів діяльності по економічній розвідці та розробці зазначеної зони, у тому числі виробництву енергії шляхом використання води, течій і вітру;

3 Конвенция Организации Объединенных Наций по морскому праву (ратифікована Законом України «Про ратифікацію Конвенції Організації Об’єднаних Націй з морського права 1982 року та Угоди про імплементацію Частини XI Конвенції Організації Об'єднаних Націй з морського права 1982 року» № 728-XIV від 03.06.1999р.) URL: https://zakon.rada.gov.ua/laws/show/995_057.

${ }^{4}$ Про виключну морську (економічну) зону: Закон України від 16.05.1995 р. // Відомості Верховної Ради України. - 1995 р., № 21, стаття 152. 
юрисдикцію, передбачену відповідними положеннями цього Закону та нормами міжнародного права, щодо створення і використання штучних островів, установок i споруд, здійснення морських наукових досліджень, захисту та збереження морського середовища;

інші права, передбачені цим Законом, іншими законодавчими актами України та загальновизнаними нормами міжнародного права.

Суверенні права та юрисдикція України щодо морського дна виключної (морської) економічної зони і його надр реалізуються відповідно до законодавства України про континентальний шельф та Кодексу України про надра.

Статтею 411 Господарського кодексу України $^{5}$ (далі - ГК України) закріплено, що з метою забезпечення суверенних прав України на розвідку, експлуатацію, збереження живих ресурсів та управління ними у виключній (морській) економічній зоні держава вживає заходів (включаючи огляд, інспекцію, арешт і судовий розгляд) щодо забезпечення додержання суб'єктами господарювання законодавства України. Держава у виключній (морській) економічній зоні України має виключне право створювати, а також дозволяти і регулювати спорудження, експлуатацію та використання штучних островів, установок і споруд для морських наукових досліджень, розвідки і розробки природних ресурсів, інших економічних цілей відповідно до законодавства України.

Відповідно до статті 1 Кодексу України про надра ${ }^{6}$ (далі- КУпН) надра - це частина земної кори, що розташована під поверхнею суші та дном водоймищ і простягається до глибин, доступних для геологічного вивчення та освоєння.

Державний фонд надр включає як ділянки надр, що використовуються, так і ділянки надр, не залучені до використання, в тому числі континентального шельфу і виключної (морської) економічної зони.

\footnotetext{
${ }^{5}$ Господарський кодекс України від 16.01.2003 р. // Офіційний вісник України.- 2003 р., № 11, стор. 303, стаття 462.

6 Про надра: Кодекс України від 27.07.1994 р. URL: https://zakon.rada.gov.ua/laws/show/132/94$\% \mathrm{D} 0 \% \mathrm{~B} 2 \% \mathrm{D} 1 \% 80$.
}

Державний фонд надр формується центральним органом виконавчої влади, що реалізує державну політику у сфері геологічного вивчення та раціонального використання надр, разом 3 центральним органом виконавчої влади, що реалізує державну політику у сфері охорони праці.

Згідно з частиною першою статті 4 КУпН надра є виключною власністю Українського народу і надаються тільки у користування. Народ України здійснює право власності на надра через Верховну Раду України, Верховну Раду АР Крим і місцеві ради.

Також, необхідно зазначити, що процедура здійснення організаційних заходів та перелік необхідних документів для погодження Мінприроди надання надр у користування у межах території України, іiі континентального шельфу та виключної (морської) економічної зони встановлена окремим документом - Регламентом погодження Мінприроди України надання надр у користування ${ }^{7}$.

Стаття 14 КУпН закріплює види користування надрами, зазначивши, що надра надаються у користування для: геологічного вивчення, в тому числі дослідно-промислової розробки родовищ корисних копалин загальнодержавного значення; видобування корисних копалин; будівництва та експлуатації підземних споруд, не пов'язаних 3 видобуванням корисних копалин, у тому числі споруд для підземного зберігання нафти, газу та інших речовин і матеріалів, захоронення шкідливих речовин і відходів виробництва, скидання стічних вод; створення геологічних територій та об’єктів, що мають важливе наукове, культурне, санітарно-оздоровче значення (наукові полігони, геологічні заповідники, заказники, пам'ятки природи, лікувальні, оздоровчі заклади та ін.); виконання робіт (здійснення діяльності), передбачених угодою про розподіл продукції; геологічного вивчення

\footnotetext{
${ }_{7}^{7}$ Про затвердження Регламенту погодження Мінприроди України надання надр у користування: Наказ Міністерства екології та природних ресурсів України від 15.02.2016 р. № 56, зареєстрований в Міністерстві юстиції України 29.02.16 за № 308/28438. URL: https://zakon.rada.gov.ua/laws/show/ z0308-16.
} 


\section{Цивільне, підприємницьке, господарське та трудове право}

бурштиноносних надр, у тому числі дослідно-промислової розробки родовищ 3 подальшим видобуванням бурштину (промисловою розробкою родовищ); задоволення інших потреб.

Згідно із пунктом 5 Порядку надання спеціальних дозволів на користування надрами ${ }^{8}$ (далі - Порядку) дозволи надаються на такі види користування надрами:

геологічне вивчення родовищ корисних копалин;

геологічне вивчення, в тому числі дослідно-промислова розробка родовищ корисних копалин загальнодержавного значення; видобування корисних копалин;

геологічне вивчення набртогазоносних надр, у тому иислі дослідно-промислова розробка родовиш, з подальшим видобуванням набби, газу (промислова розробка родовищ);

будівництво та експлуатація підземних споруд, не пов'язаних з видобуванням корисних копалин, у тому числі споруд для підземного зберігання нафти, газу та інших речовин і матеріалів, захоронення шкідливих речовин і відходів виробництва, скидання стічних вод;

створення геологічних територій та об'єктів, що мають важливе наукове, культурне, санітарно-оздоровче значення (наукові полігони, геологічні заповідники, заказники, пам'ятки природи, лікувальні, оздоровчі заклади тощо);

виконання робіт (здійснення діяльності), передбачених угодою про розподіл продукий.

Так, надра надаються у користування підприємствам, установам, організаціям і громадянам лише за наявності у них спеиіального дозволу на користування ділянкою надр. Право на користування надрами засвідчується актом про надання гірничого відводу (частина перша статті 19 КУпН).

При укладенні угод про розподіл продукції надра надаються в користування на підставі угоди про розподіл продукиій з оформленням спеціального дозволу на користування надрами та акта про надання гірничого відводу.

\footnotetext{
${ }^{8}$ Про затвердження Порядку надання спеціальних дозволів на користування надрами: Постанова Кабінету Міністрів україни від 30.05.2011 р. № 615 . URL: https://zakon.rada.gov.ua/laws/show/615-2011$\%$ D0\%BF\#Text .
}

Разом з цим слід вказати на виключення і зазначити, що користувачі нафтогазоносними надрами, які отримали спеціальний дозвіл на користування такими надрами, не потребують гірничого відводу (ст.17 КУпН).

Згідно статті 8 КУпН укладення угод про розподіл продукції щодо використання ділянок надр у виключній (морській) економічній зоні, на континентальному шельфі України у галузі геологічного вивчення, використання і охорони надр належить до відання Кабінету Міністрів України

Особливості користування надрами під час виконання угоди про розподіл продукції, у тому числі пов'язані 3 наданням, передачею, обмеженням, тимчасовою забороною (зупиненням) та припиненням права користування надрами, а також 3 правовим оформленням таких відносин, регулюються Законом України «Про угоди про розподіл продукції» ${ }^{9}$ (далі - Закон про угоди про розподіл продукції).

Закон про угоди про розподіл продукції спрямований на створення сприятливих умов для інвестування пошуку, розвідки та видобування корисних копалин у межах території України, ії континентального шельфу та виключної (морської) економічної зони на засадах, визначених угодами про розподіл продукції.

Статтею 6 Закону про угоди про розподіл продукції визначено, що угоди про розподіл продукції відповідно до цього Закону можуть укладатися щодо окремих ділянок (ділянки) надр, що обмежуються у просторі та координатами, в межах яких знаходяться родовища, частини родовищ корисних копалин загальнодержавного і місцевого значення, включаючи ділянки надр у межах континентального шельбу та виключної (морсъкої) економічної зони України.

Угода про розподіл продукції укладається з переможцем конкурсу з урахуванням умов конкурсу та конкурсної заявки переможця, або, у випадках, передбачених абзацом п’ятнадцятим частини першої статті 7 Закону про угоди про розподіл продукції - 3

\footnotetext{
${ }^{9}$ Про угоди про розподіл продукції: Закон України від 14.09.1999 р. URL: https://zakon.rada.gov.ua/laws/ show/1039-14.
} 
переможцем конкурсу та господарським товариством (частина 4 статті 6 Закону).

Порядок проведення та умови конкурсу на укладення угод про розподіл продукції визначаються статтею 7 Закону про угоди про розподіл продукції.

За рішенням КМ України та органу місцевого самоврядування угода про розподіл продукції може бути укладена без проведення конкурсу щодо ділянок надр із незначними запасами корисних копалин, що підтверджується висновками відповідних державних органів (частина 5 статті 6 Закону про угоди про розподіл продукції).

У разі якщо надрокористувач, який має спеціальний дозвіл на користування надрами і розпочав діяльність на передбачених ним умовах, виявив бажання укласти угоду про розподіл продукції, така угода (двостороння або багатостороння) за рішенням Кабінету Міністрів України також може бути укладена без проведення конкурсу. Після укладення угоди про розподіл продукції спеціальний дозвіл на користування надрами підлягає переоформленню відповідно до положень Закону про угоди про розподіл продукції та в порядку, передбаченому такою угодою (абзац 10 частини 5 статті 6 Закону про угоди про розподіл продукції).

Угоди про розподіл продукції, укладені щодо пошуку, розвідки та видобування вуглеводневої сировини, а також щодо використання родовищ із значними запасами корисних копалин, крім істотних умов, зазначених у статті 8 Закону про угоди про розподіл продукції, повинні передбачати також такі істотні умови: щорічне декларування видобувних характеристик; порядок користування геологічною, геофізичною та іншою інформацією; порядок і особливості обліку витрат на промислові та технологічні потреби; порядок і строки оцінки рівня забруднення довкілля в районі експлуатації ділянки надр (земельної ділянки, наданої для потреб, пов'язаних з користуванням надрами) на момент укладення угоди; обсяги і строки виконання природоохоронних заходів; порядок узгодження та затвердження програм робіт, зокрема програм проведення нафтових операцій; умови відповідального зберігання державної частки видобутих ко- рисних копалин до передачі їх державі; умови страхування майнових ризиків, включаючи втрату видобутих корисних копалин внаслідок розливу, повені, пожежі; умови виключного ризику під час розробки родовищ (стаття 9 Закону про угоди про розподіл продукції).

Строк дії угоди про розподіл продукції визначається сторонами, однак не може перевищувати п'ятдесяти років 3 дня ії підписання (частина 1 статті 14 Закону про угоди про розподіл продукції).

Таким чином, можна дійти висновку, що користування газоносними надрами (видобування енергетичних ресурсів - нафти i газу) в межах виключної економічної зони України можливе як за наявності спеціального дозволу на користування надрами, так і на підставі укладення угоди про розподіл продукції з оформленням спеціального дозволу на користування надрами.

Цей висновок також підтверджується й пунктом 7 Порядку, яким визначено, що дозвіл на користування надрами, а саме енергетичними ресурсами в межах виключної економічної зони України, надається на строк, визначений заявником, але не більш як на:

- 30 років - на видобування нафти і газу в межах континентального шельфу та виключної (морської) економічної зони України;

- строк дії окремих дозволів на геологічне вивчення нафтогазоносних надр та видобування нафти і газу (промислова розробка родовищ), але не більш як на 20 років на суші і не більш як на 30 років на континентальному шельфі та в межах виключної (морської) економічної зони України - на геологічне вивчення нафтогазоносних надр, у тому числі дослідно-промислову розробку родовищ, $з$ подальшим видобуванням нафти і газу (промислова розробка родовищ). При цьому строк геологічного вивчення нафтогазоносних надр не може перевищувати 10 років;

- строк дії відповідної угоди про розподіл продукції - на виконання угод про розподіл продукції.

Стаття 15 КУпН закріплює, що перебіг строку користування надрами починаєть- 


\section{Цивільне, підприсмницьке, господарське та трудове право}

ся 3 дня одержання спеціального дозволу (ліцензії) на користування надрами, якщо в ньому не передбачено інше, а в разі укладення угоди про розподіл продукції - $з$ дня, зазначеного в такій угоді.

Регулювання питань надання спеціальних дозволів на користування надрами (далі дозволи) у межах території України, їі континентального шельфу та виключної (морської) економічної зони, а також визначення процедури продовження строку дії, переоформлення, зупинення дії чи анулювання дозволу та внесення до нього змін передбачено Порядком надання спеціальних дозволів на користування надрами.

Згідно $з$ пунктом 2 Порядку, спеціальні дозволи на користування надрами (далі дозволи) надаються Державною службою геології та надр України (Держгеонадрами України) переможиям аукиіонів з їх продажу та без проведення аукиіонів у випадках, передбачених пунктом 8 Постанови КМУ про надання дозволів, органом 3 питань надання дозволу, крім корисних копалин місцевого значення на території Автономної Республіки Крим, дозволи на видобування яких надаються Радою міністрів Автономної Республіки Крим.

Порядок, що визначає процедуру продажу на аукціоні спеціального дозволу на користування надрами у межах території України, пї континентального шельфу та виключної (морської) економічної зони затверджений постановою Кабінету Міністрів України «Про затвердження Порядку проведення аукціонів 3 продажу спеціальних дозволів на користування надрами» ${ }^{10}$.

Пунктом 8 Порядку закріплено, що без проведення аукціону дозвіл надається, серед іншого, у разі виконання угод про розподіл продукиї.

Спеціальний дозвіл на користування надрами на умовах розподілу продукції видається на підставі укладеної угоди про розподіл продукції і повинен містити усі види користування надрами та інші дані та відо-

\footnotetext{
${ }^{10}$ Про затвердження Порядку проведення аукціонів 3 продажу спеціальних дозволів на користування надрами: Постанова Кабінету Міністрів України від 30.05.11 № 594. URL: https://zakon.rada.gov.ua/ laws/show/594-2011-\%D0\%BF .
}

мості, передбачені цією угодою (частина 10 статті 16 КУпН).

Пунктом 9 Порядку передбачено, що погодження надання надр у користування на виконання угод про розподіл продукції здійснюється у порядку та на умовах, визначених Законом України «Про угоди про розподіл продукції» і відповідними угодами про розподіл продукції.

Пунктом 10 Порядку визначено, що невід'ємною частиною дозволу на користування надрами є угода про умови користування надрами, що укладається між органом 3 питань надання дозволу і надрокористувачем і містить програму робіт, яка оформляеться як додаток, та особливі умови надрокористування.

Згідно пункту 11 Порядку у разі надання дозволу на користування надрами у межax континентального шельфу та виключної (морської) економічної зони України визначається площа морського дна (ділянки надр) із зазначенням координат, у яких дозволяється провадження діяльності, передбаченої у дозволі.

В угоді про умови користування ділянкою нафтогазоносних надр, що розташована в межах континентального шельфу або виключної (морської) економічної зони України, укладеній між Держгеонадрами і надрокористувачем, можуть установлюватися відповідно до законодавства додаткові вимоги.

\section{Література}

1. Про затвердження Морської доктрини України на період до 2035 року: Постанова Кабінету Міністрів України від 07.10.2009 р. № 1307. URL: https://zakon.rada.gov.ua/laws/ show/1307-2009-\%D0\%BF.

2. Про національну безпеку України: Закон України від 21.06.2018 p. URL: https:// zakon.rada.gov.ua/laws/show/2469-19.

3. Конвенция Организации Объединенных Наций по морскому праву (ратифікована Законом України «Про ратифікацію Конвенції Організації Об'єднаних Націй з морського права 1982 року та Угоди про імплементацію Частини XI Конвенції Організації Об'єднаних Націй з морського права 1982 року» № 728-XIV від 03.06.1999 р.). URL: https://zakon.rada.gov.ua/laws/show/995_057. 
4. Про виключну морську (економічну) зону: Закон України від 16.05.1995 р. // Вiдомості Верховної Ради України. - 1995 р., № 21, стаття 152 .

5. Господарський кодекс України від 16.01.2003 р. // Офіційний вісник України.2003 р., № 11, стор. 303, стаття 462.

6. Про надра: Кодекс України від 27.07.1994 p. URL: https://zakon.rada.gov.ua/ laws/show/132/94-\%D0\%B2\%D1\%80.

7. Про затвердження Порядку надання спеціальних дозволів на користування надрами: Постанова Кабінету Міністрів україни від 30.05.2011 р. № 615. URL: https://zakon.rada.gov.ua/laws/show/615-2011$\%$ D0\%BF\#Text.

8. Про угоди про розподіл продукції: Закон України від 14.09.1999 p. URL: https:// zakon.rada.gov.ua/laws/show/1039-14.

9. Про затвердження Регламенту погодження Мінприроди України надання надр у користування: Наказ Міністерства екології та природних ресурсів України від 15.02 .2016 р. № 56, зареєстрований в Міністерстві юстиції України 29.02.16 р. за № 308/28438. URL: https://zakon.rada.gov.ua/ laws/show/z0308-16.

10. Про затвердження Порядку проведення аукціонів з продажу спеціальних дозволів на користування надрами: Постанова Кабінету Міністрів України від 30.05.11
№ 594. URL: https://zakon.rada.gov.ua/laws/ show $/ 594-2011-\%$ D0\%BF.

\section{Ustymenko Tetiana, Shapoval Lesya \\ THE LEGAL ASPECTS OF ENERGY \\ RESOURGES EXTRACTION WITHIN THE EXCLUSIVE ECONOMIC ZONE OF UKRAINE}

The authors analyzed the relevant norms of international maritime law and Ukrainian legislation in the context of energy resources extraction within the exclusive economic zone of Ukraine.

In 1999, the Law on Production Sharing Agreements was adopted by Ukraine, which aims to create favorable conditions for investing in the search for minerals, exploration and production of minerals, including hydrocarbons, within the territory of Ukraine, its continental shelf and the exclusive (maritime) economic zone on the basis of the Production Sharing Agreements.

The authors of the article concluded that the possibility of extracting energy resources (oil and gas) within the exclusive economic zone of Ukraine both in the presence of a special permit and on the basis of the Production Sharing Agreements with registration of the special permission for subsoil use.

Keywords: extraction of mineral resources, hydrocarbon, exclusive economic zone, Production Sharing Agreements, the Black Sea, the Sea of Azov, hydrocarbon. 